\title{
Diskursus Branding Perempuan Pondok Pesantren di Instagram (Studi Kasus Pondok Pesantren Modern Gontor Putri 1)
}

\author{
Robby Aditya Putra \\ IAIN Curup \\ robbyadityaputra@gmail.com
}

\begin{abstract}
Women's aspirations for education are so that women and men are equally placed as whole human beings in various aspects of life. Pesantren are aware of this, the proof is that there are many female-only pesantren held. However, some modern societies still consider pesantren branding as "ndeso" and tend to produce normative women, who have not produced millennial women that are relevant to the times. Then how do the branding efforts of the modern boarding school Gontor Puri 1 about millennial era women on Instagram? The theory used in this paper is the theory of advertising and branding from David Aaker. This study found that there was no seriousness of the Gontor Putri 1 branding effort on millennial women on Instagram. As a result of this lack of seriousness, the brand of boarding school as an ancient institution and not in accordance with the characteristics of millennial women will survive.The effort of 'rebranding' pondok pesantren through social media (Instagram, Facebook, Twitter, YouTube) must be one of the main focuses of the boarding school stakeholders to be creatively campaigned.
\end{abstract}

Keywords: Brand, Women Millennial, Instagram, Pondok Pesantren, Gontor Putri

\begin{abstract}
Abstrak
Cita-cita perempuan mengenyam pendidikan adalah agar perempuan dan laki-laki sama-sama ditempatkan sebagai manusia utuh di berbagai aspek kehidupan. Pesantren menyadari hal ini, terbukti dengan banyak pesantren khusus perempuan yang digelar. Namun sebagian masyarakat modern masih menganggap branding pesantren adalah 'ndeso' dan cenderung menghasilkan perempuan yang normatif, belum banyak mencetak perempuan milenial yang relevan dengan zaman. Lalu bagaimanakah upaya branding pondok pesantren modern gontor puri 1 tentang perempuan era milenial di instagram? Teori yang dipakai dalam tulisan ini adalah teori advertising and branding dari David Aaker. Penelitian ini menemukan belum adanya keseriusan upaya branding gontor putri 1 tentang perempuan milenial di instagram. Akibat ketidakseriusan ini, brand pondok pesantren sebagai lembaga kuno dan tidak sesuai dengan karakteristik perempuan milenial akan bertahan. Usaha rebranding pondok pesantren melalui media sosial
\end{abstract}


(instagram, facebook, twitter, youtube) harus menjadi salah satu fokus utama pemangku pondok pesantren untuk dikampanyekan secara kreatif.

Kata Kunci: Brand, Perempuan Milenial, Instagram, Pondok Pesantren, Gontor Putri

\section{Pendahuluan}

Di Indonesia, pondok pesantren masih menggema sebagai lembaga pendidikan yang diandalkan karena memiliki kontribusi besar dalam menyumbangkan putra-putri bangsa handal sebagai instrument pengisi 72 tahun kemerdekaan Indonesia. Pondok pesantren ikut mencerdaskan bangsa dan mengeliminir munculnya kapitalisme sekolah yang dijadikan ladang bisnis oknum tertentu, sehingga tidak semua masyarakat dapat menjangkau. ${ }^{1}$ Sebaiknya pesantren seharusnya tidak dipilih karena aspek murahnya saja, tapi karena kualitasnya yang setara bahkan mengungguli dalam beberapa bidang jika dibandingkan dengan sekolah umum.

Kenyataan brand pesantren sebagai sekolah 'ndeso' dan bersifat akhirati cenderung masih menjadi brand utama bagi sebagian masyarakat modern. Padahal banyak sekali kultur dan nilai-nilai luhur pendidikan pesantren yang kalau mau ditelisik secara serius dan objektif, sarat akan makna. Karena pesantren tidak hanya semata-mata memperkaya pikiran murid dengan ilmu, tapi juga meningkatkan moral, melatih dan mempertinggi semangat, nilai kemanusiaan, jujur, sederhana dan bermoral. ${ }^{2}$

Brand 'ndeso' akan menjadikan pesantren dipilih hanya karena 'murah' saja. Oleh karena itu, rebranding pesantren adalah solusi untuk meningkatkan partisipasi masyrakat dalam menitipkan anaknya di pesantren. Tanpa rebranding, maka pondok pesantren perlahan akan ditinggalkan, terutama bagi keluarga modern yang masih menganggap dalam sistem pendidikannya, pesantren hanya menggunakan narasi konvensional. Untuk merumuskan strategi rebranding, perlu diuraikan lebih dalam seperti apa pesantren membranding dirinya sendiri. Dalam tulisan ini branding pondok pesantren modern gontor puri terkait pendidikan perempuan era milineal di instagram.

Pondok, kiyai dan santri adalah tiga komponen utama dalam sistem pendidikan pesantren. Oleh karena itu, tidak lengkap rasanya membahas pesantren jika tidak membahas santri perempuan(santriwati). Cita-cita perempuan mengenyam pendidikan adalah agar perempuan dan laki-laki sama-sama ditempatkan sebagai manusia utuh di berbagai aspek kehidupan. Hal ini dilegitimasi oleh ayat ke-35 dari Surat Al-Ahzab yang secara ekplisit mengakui kesetaraan laki-laki dan perempuan, yang berbunyi: 2008), 12.

${ }^{1}$ Syamslul Maarif, Pesantren VS Kaapitalisme Sekolah (Semarang: NEED'S Press,

${ }^{2}$ Dhofier Zamachsyari, Tradition and Change in Indonesia Islamic Education (Jakarta: DEPAG: 1995), 18. 

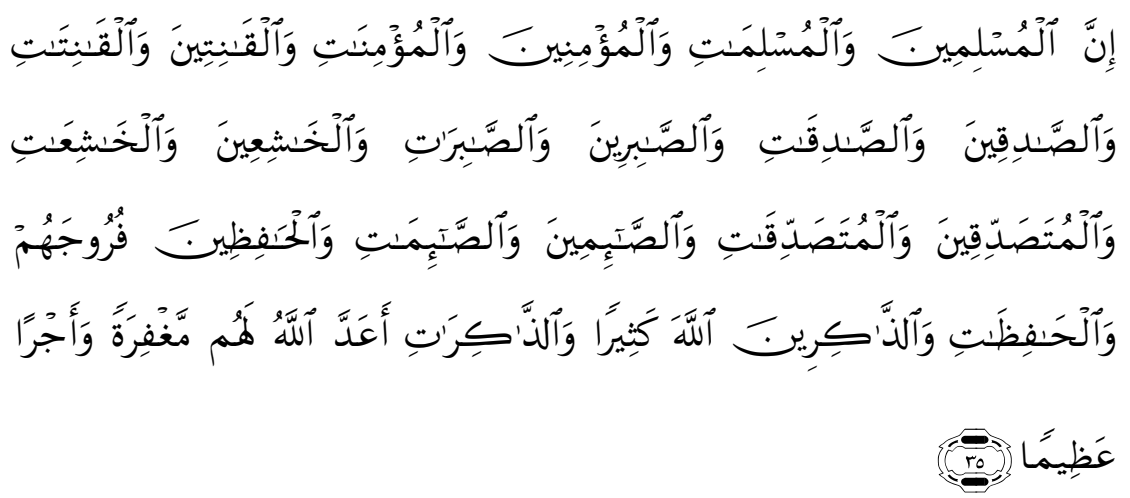

"Sesunggubnya laki-laki dan perempuan yang muslim, laki-laki dan perempuan yang mu'min, laki-laki dan perempuan yang tetap dalam keta'atannya, laki-laki dan perempuan yang benar, laki-laki dan perempuan yang sabar, laki-laki dan perempuan yang kbusyu', laki-laki dan perempuan yang bersedekah, laki-laki dan perempuan yang berpuasa, laki-laki dan perempuan yang memelihara kehormatannya, laki-laki dan perempuan yang banyak menyebut (nama) Allah, Allah telah menyediakan untuk. mereka ampunan dan pahala yang besar: ${ }^{3}$

Nyatanya salah satu tantangan perempuan era milineal adalah, ketika perempuan lantang berpendapat di berbagai linimasa, masyarakat cenderung berlomba mendiskriminasi dengan mengingatkan kepada kodrat, bahwa sebaiknya perempuan segeralah mengurusi urusan rumah saja. Padahal betapa menyenangkan ketika brand perempuan tidak hanya dianggap dari sisi emosional saja, melainkan sebagai subjek yang menguasai momentum.

Pesantren menyadari bahwa pendidikan sangat dibutuhkan dan penting bagi perempuan. Terbukti dengan banyaknya pesantren khusus perempuan yang digelar. Namun karena brand 'ndeso' masih melekat, maka sebagian masyarakat modern menganggap pesantren cenderung menghasilkan perempuan yang normatif, belum banyak mencetak perempuan milenial yang relevan dengan zaman. Karena sistem pendidikan yang diajarkan tentang perempuan masih menggunakan narasi konvensional. Diskursus perempuan berputar pada urusan kasur, dapur dan sumur. Dengan brand seperti itu, sebagian orang tua enggan menitipkan anak perempuannya di pesantren, melainkan di sekolah umum.

Padahal fungsi pendidikan adalah menciptakan ruang agar santri mempunyai sikapkritis terhadap sistem yang tidak adil, serta melakukan konstruksi menuju sistem sosial yang lebih adil. Sehingga peserta didik, baik laki-laki dan perempuan, dipupuk kesadarannya supaya dapat bersikap kritis terhadap realitas yang dihadapinya. Begitulah sebenarnya fungsi lembaga pendidikan yang digembor-gemborkan Paulo Freire, Ivan Illich, Philip H. Coombs, Everett Reimer. 
Mereka adalah para penggugat pendidikan, (pembawa aliran baru pendidikan). Tujuan ini tidak diperuntukkan bagi santri laki-lakisaja, melainkan santri perempuan juga. Dan sebagian masyarakat modern tidak melihat fungsi ini dimiliki oleh pesantren.

Brand tersebut menjadi manarik ketika dikoherensikan dengan pondok pesantren Darussalam Gontor Putri1. Alasan dipilihnya ponpes ini adalah karena pondok ini adalah salah satu pondok yang sudah berdiri lama, yaitu diresmikan tahun 1990 oleh Menteri Agama Munawir Sadzali, M.A. ${ }^{4}$ Dan mempunyai track record yang bagus dalam hal pendidikan dan telah berhasil mencetak perempuan handal. Agar tulisan ini fokus, maka penulis akan meneliti upaya branding pondok pesanren Darussalam gontor putri 1 di platform instagram. Karena instagram adalah platform kekinian yang meiliki users terbanyak kedua setelah facebook. Ratarata users instagram adalah remaja (laki-laki-perempuan). Teori yang dipakai adalah teori advertising and branding dari David Aaker, dan akan direlevansikan dengan karakeristik perempuan milenial.

Setiap hari manusia berkomunikasi. Sadar ataupun tidak sadar, Sengaja atau tidak sengaja. Manusia selalu berkomunikasi. Komunikasi adalah aktivitas vital dalam berkehidupan. Tak heran jika Charles Atkin mengatakan bahwa manusia tidak bisa tidak berkomunikasi. ${ }^{5}$ Setiap hari, manusia pasti berkomunikasi secara verbal maupun nonverbal. Oleh karena itu, komunikasi dianggap sebagai mata rantai kehidupan. Inilah salah satu akar terciptanya masyarakat madani, berdasarkan pendekatan Thomas Janoski yang menyatakan bahwa masyarakat madani dapat tercipta melalui diskursus intensif antara negara, pasar, publik, dan pribadi. $^{6}$

Paralel dengan itu, setiap hari manusia juga melihat iklan. Ikaln juga erat kaitannya dengan bkegiatan branding. Mulai dari bangun tidur sudah terkena terpaan iklan, seperti suara iklan di televisi, tukang sayur meneriakkan daganganya, dan lain-lain. Ketika akan melaksanakan aktivitas, di jalan pun terdapat iklan, seperti spanduk, billboard dan di badan bus transjakarta. Apalagi ketika pemilu, jalan raya dibanjiri gambar para calon. Iklan merupakan alat komunikasi yang efektif untuk membranding suatu produk. Karena alasan itu, maka pelaku usaha berbondong-bondong mengiklankan produknya agar laku di pasar. Komunikasi, iklan dan brand saling berkaitan.

\footnotetext{
${ }^{4}$ http:/ / www.gontor.ac.id/pondok-modern-darussalam-gontor-putri-1

${ }^{5}$ Charles Atkin, Human Communication Principles, Contexts and Skills, (New York, Martin Press, 1980), 6.

${ }^{6}$ Andi Faisal Bakti, Literasi Politik dan Konsolidasi Demokrasi (Jakarta: Churia Press, 2012) 1-27.
} 
Ketika berbicara mengenai komunikasi, tak lengkap rasa nya jika tidak menyinggung dakwah. karena secara fundamental, dakwah dan komunikasi adalah saudara dekat. Dakwah merupakan denyut nadi Islam, ${ }^{7}$ yang bertujuan untuk melarang masyarakat melakukan kemaksiatan. ${ }^{8}$ Dalam beberapa kajian literatur, pemakalah menemukan banyak definisi terkait dakwah dan komunikasi. Jika dibandingkan, keduanya hampir sama persis. Dakwah mempunyai dimensi yang sama dengan komunikasi, yaitu sebagai proses pertukaran informasi melalui bahasa verbal dan non-verbal kepada individu maupun masyarakat, bertujuan dan mengharapkan umpan balik (feed-back). Dalam konteks dakwah, untuk hijrah kepada kebaikan dan meninggalkan keburukan (amar ma'ruf nabi munkar). Kedua kajian ilmu ini mempunyai unsur yang sama-sama berkutat di ranah komunikator (da'i), message(maddah), audiens (mad'u), media (wasilah), umpan balik, dan dampak.

Oleh karena dakwah dan komunikasi memiliki kesamaan secara fundamental, maka untuk mengetahui makna dakwah secara utuh, kita dapat meminjam teori Laswell yang mengatakan bahwa untuk mengetahui proses komunikasi secara komprehensif, perlu menjawab pertanyaan (Who) siapa yang mengatakan? (Say What) mengatakan tentang apa? (In What Channel) menggunakan media apa? (To Whom) kepada siapa? dan (With What Effect) menghasilkan efek apa?

Setelah menjabarkan latar belakang dan permasalahan di atas, tulisan ini dimaksudkan untuk menganalisa secara kritis tentang bagaimana fenomenadiskursus branding pondok pesantren modern Gontor Putri1 tentang pendidikan perempuan era milineal di instagram perspektif advertising and branding? Selanjutnya, narasi besar ini akan dijabarkan melalui pertanyaan yang lebih spesifik seperti: apakah akivitas di instagram tersebut telah mampu menghadirkan sebuah produk di hati masyarakat? Dengan apa brand gontor putri, menyajikan keunggulan lembaga nya? Serta apa saja konstruksi identitasyang ingin dibentuk?

Tulisan ini memilih pondok pesantren modern gonor putri 1 sebagai sampel studi kasus. Pesantren Putri Pondok Modern Darussalam Gontor, terletak di sebelah barat kota Ngawi, tepatnya di desa Sambirejo Kec. Mantingan Kab. Ngawi. Pesantren Putri Pondok Modern Darussalam Gontor diresmikan oleh Menteri Agama Republik Indonesia, H. Munawir Syadzali, M.A. Meskipun begit, pesantren putri ini sudah dibuka sejak mulai tahun ajaran $1410-1411$ di desa Sambirejo, Mantingan, Ngawi , Jawa Timur. Sistem pendidikan di KMI Pondok Modern Darussalam Gontor Putri sepenuhnya mengacu kepada sistem pendidikan

${ }^{7}$ Moh Ali Aziz, Ilmu Dakwah (Jakarta: Kencana, 2009.Rev.ed), 4-5.

${ }^{8}$ Salah satu tujuan dakwah adalah melarang manusia untuk berbuat dosa, contoh nya berjudi dan konsumsi alkohol dengan menggukan pendekatan budaya pribumi. K. van Dijk, "Dakwah and Indigenous Culture; The Dissemination of Islam", in: Bijdragen tot de Taal-, Land- en Volkenkunde. Vol. 154 no: 2, Leiden, (1998), 218-235.

${ }^{9}$ Denis McQuail dan Seven Windahl, Communication Models for Study of Mass Communications (New York: Longman, 1993), 13. 
KMI Pondok Modern Darussalam Gontor; baik dalam jenjang pendidikan maupun kurikulumnya.

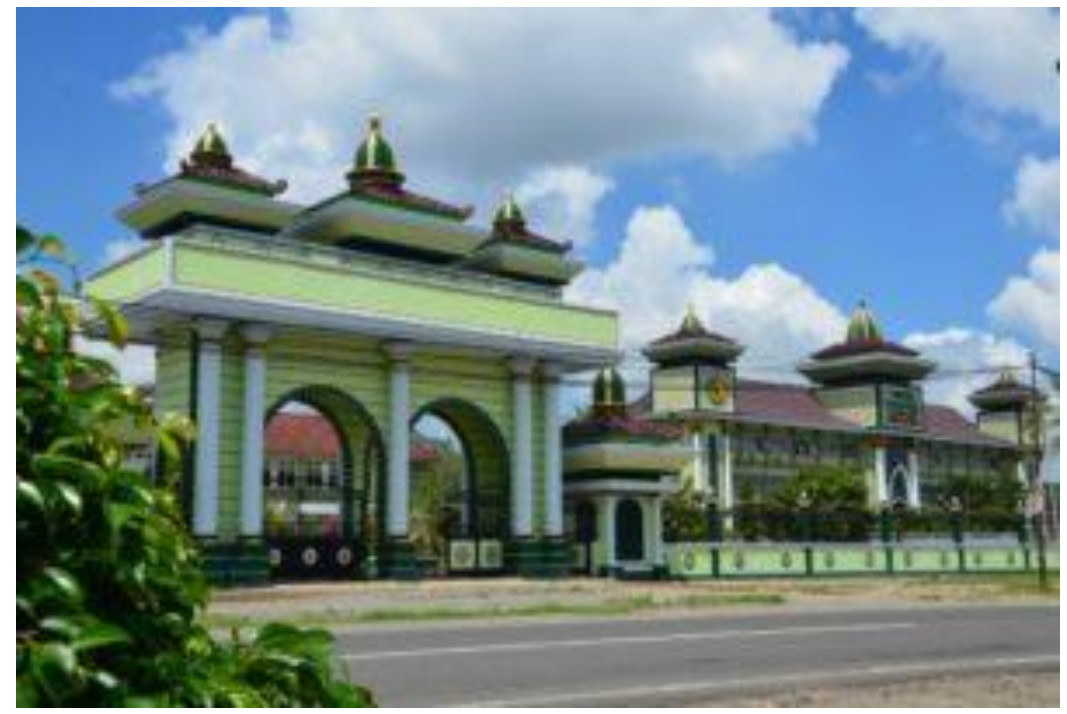

Gambar 1. Gerbang Pesantren Putri Pondok Modern Darussalam Gontor

Santriwati mendapat bimbingan, pengajaran, dan pengembangan diri secara intensif oleh Pengasuhan Santriwati yang bertanggungjawab menangani berbagai aktivitas ekstrakurikuler yang meliputi keorganisasian, kepramukaan, bahasa, disiplin, olahraga, ketrampilan, kesenian, akhlak, ibadah, nisaiyat, dan berbagai aktifitas keputrian lainnya. ${ }^{10}$

Gontor puri sebenarnyaa dalah satu kesatuan dengan gonor putri dua, tiga dan seterusnya. Pimpinan pusatnya ada di gontor putra satu Ponorogo, selain itu adalah cabangnya. Sega seuatu urusan merujuk pada pusat. ${ }^{11}$ Di gontor putri, bahasa yang wajib digunakan adalah bahasa Arab dan Inggris. Santri akan terus dicecoki kedua bahsa tersebut disetiap pembelajaran dan keseharian. Jika tidak akan mendapatkan hukuman.

${ }^{10}$ Diakses melalui ttps://www.gontor.ac.id/pondok-modern-darussalam-gontorputri-1, pada 28 September 2018.

11 Wawancara dengan Nurul Ani, alumni gontor putri 1 tahun 2002, pada 26 September 2018. 


\section{Pernyataan Tujuan dan Signifikansi Penelitian}

Terkait dengan signifikansi, penelitian ini diharapkan dapat:

1. Memberikan informasi dan membuka wawasan luas tentang branding dan pondok pesantren, sehingga dapat memberikan kontribusi bagi para pelaku dakwah dan praktisi advertising.

2. Memberikan gambaran nyata kepada praktisi amar ma'ruf nabi munkar tentang sejauh mana branding pondok pesantren melalui media sosial.

3. Memberikan solusi nyata agar pondok pesantren lebih fokus branding melalui media sosial khususnya instagram.

\section{Hasil dan Pembahasan}

Kegiatan online melalui instagram menjadi aktifitas yang popular di tengah masyarakat modern. Setiap hari kita disuguhkan berbagai macam informasi di platform ini.Teknologi modern yang berkembang harus bisa dimanfaatkan untuk hal-hal kebaikan, menguntungkan dan juga sebagai aktivitas branding. ${ }^{12}$ Menurut Evan Carrol, branding melalui media maya lambat laun mengubah cara manusia dalam berinterakasi. ${ }^{13}$ Media instagram adalah media kekinian yang memiliki users sebanyak 1 miliar per-juni 2018.14 Oleh karena itu, instagram akan sangat berpengaruh bagi eksistensi suatu komunitas atau lembaga untuk saling berbagi informasi. Lembaga yang tidak sadar akan kekuatan media akan dianggap konvensional, bahkan dianggapkuno dan tidak relevan dengan zaman.

Media komunikasi modern efektif untuk menghibur sekaligus menyampaikan pesan yang dapat mempengaruhi sikap, pola pikir dan membuka wawasan bagi komunikannya. ${ }^{15}$ Melalui media inilah pihak-pihak tertentu melakukan propaganda dan mensosialisasikan ide dan pesannya kepada masyarakat. Pesan-pesan melalui media itu, kemudian menimbulkan efek yang berbeda-beda pada masyarakat sesuai dengan pemakaannya.

Banyak kementerian yang juga sudah memanfaatkan platform instagram sebagai media untuk menyebarkan informasi. Kementerian Agama dengan nama akun@kemenag_ri, jumlah follower 166ribu. Kementerian Pariwisata RI dengan

${ }^{12}$ Andi Faisal Bakti, Globalisasi: Dakwah Cerdas Era Globalisasi Antara Tantangan Dan Harapan, https://c3huria.com/2015/01/28/globalisasi-dakwah-cerdas-era-globalisasiantara-tantangan-dan-harapan/ di akses pada 17 Maret 2015.

${ }^{13}$ Evan Carroll and John Romano, "Your Digital Afterlife: When Facebook, Flicker and Twitter Are Your Estate, What's Your Legacy?” (Berkeley: New Riders, 2011), 14 dan 32, Di unduh melalui www.libgen.org. Diakses 03 Juni 2015.

${ }^{14}$ Diakses melalui https://tekno.kompas.com/read/2018/06/21/10280037/juni2018-pengguna-aktif-instagram-tembus-1-miliar, pada 28 September 2018.

${ }^{15}$ http://inang.blogdetik.com/inang-the-movie/latar-belakang/, diakses pada tgl 28 September 2018, jam: 11.22. 
nama akun@kemenpar, jumlah follower 244 ribu. Kementerian BUMN dengan nama akun@kementerianbumn, jumlah follower 289 ribu, dan kementerian lainnya. ${ }^{16}$ Kesadaran membranding lembaga dengan instagram adalah sebuah keniscayaan, karena instagram dinilai efektif dan efisien dengan karakteristiknya yang simple dan elegan, dan terasa dengan masyarakat karena banyak yang memiliki akun instagram.

Termasuk juga Ditpdpontren Kemenag sudah memanfaatkan instagram dalam menyebarkan informasi kegiatannya dengan nama akun (a) pendidikanpesantren. Jumlah follower 7047 dan 487 postingan. Akun (a) pendidikanpesantren tampak dikelola serius oleh tim khusus. Karena postingan yang diupload berkonsep dan menarik. Tidak hanya instagram, Ditpdpontren Kemenag (@pendidikanpesantren) juga sudah mulai aktif melalui facebook, twitter dan youtube. Keseriusan ini patut diapresiasi bersamauntuk dipertahankan dan terus ditingkatkan.

Dilain pihak, perempuan milenial memiliki perbedaan jika dibandingkan dengan era sebelumnya. Mereka mempunyaiorientasi pendidikan lebih baik, pemikiram yang lebih maju. Sehingga dengan pendidikan itu, mereka makin kritis terhadap ketimpangan yang berbau gender. ${ }^{17}$ Perempuan milenial memiliki karakterisik yang percaya diri (confident), harapan tinggi (high expectations), dan berorientasi pada pencapaian (achievement oriented). ${ }^{18}$

Hasanuddin Ali menyebutkan ada tiga karakter yang dimiliki milenial. Mereka adalah pribadi yang connected, memiliki gaya berpikir yang kreatif dan percaya diri. Di era kekinian ini, banyak perempuan milenial yang bias dijadikan contoh, seperti Diajeng Lestari (32) dan Catherine Hindra Sutjahjo (35) yang mendirikan start up business HIJUP dan Zalora. ${ }^{19}$ Dengan karakterisitik seperti ini, perempuan milenial ingin ditempatkan sebagai subjek yang mewarnai beberagai bidang agar setara dengan laki-laki. Pendidikan pondok pesantren tentang perempuan sejatinya juga mampu menerapkan sistem yang kemudian akan mencetak perempuan yang sesuai dengan karakterisik perempuan milenial. Banyak kita temukan alumni pondok pesantren yang tidak hanya kapabel, tapi juga memiliki akhlak yang baik, sopandan santun.

16 Instagram.com/kemenag_ri, Instagram.com/kementerianbumn, Instagram.com/kemenpar

${ }^{17}$ Akhmad Muawal Hasan, Ketimpangan Gender dan Kendali Perempuan Milenial, diakses di https://tirto.id/ketimpangan-gender-dan-kendali-perempuan-milenial-cnb5, pada 28 September 2018. diakses

${ }^{18}$ Emy Susanti, Pemikiran Kartini dan Peran Perempuan di Era Milineal. Susanti, www.unair.ac.id/uploads/file/978da696984c5a895213abf56b6e0c43.pdfpada 27 September 2018.

${ }^{19}$ Tsamara Amany, Perempuan Milenial Progresif, diakses di https://news.detik.com/kolom/3835100/perempuan-milenial-progresif pada 28 Sepember 2018. 
Hal itu akan tertupi bila, para pemangku pondok pesantren tidak memahami esensi branding, tidak melakukan upaya brand yang tampak berkata sebaliknya, ditambah juga tidak ramah terhadap teknologi.

Beberapa ahli memaknai iklan dalam beberapa pengertian. Ada yang mengartikan dalam kacamata komunikasi, murni periklanan, pemasaran, sosiologi dan ada pula yang memaknai secara psikologi. Semua pengertian ini mempunyai arah dan konsekuensi yang berbeda. Makalah ini akan fokus membahas iklan dari sudut pandang komunikasi. Dalam perspektif komunikasi, iklan merupakan proses penyampaian pesan dari komunikator kepada komunikan, bersifat komunikatif dan persuasif. Bertujuan untuk mendorong, membujuk, atau memanipulasi penonton. ${ }^{20}$

Muncul perbedaan pendapat mengenai asal-asul kata iklan. Menurut Otto Klepper (2000), ${ }^{21}$ iklan berasal dari bahasa Latin, advere, yang berarti mengalihkan pikiran dan gagasan kepada orang lain. Sedangkan KH Zarkasi Effendy mengatakan bahwa iklan berasal dari bahasa Arab, yaitu i'lan, yang berarti pengumuman, pemberitahuan, penyiaran. ${ }^{22}$

Terlepas dari perbedaan itu, sejarah periklanan ditemukan bersamaan dengan sejarah penyiaran publik di Yunani dan Romawi. Pada saat itu mereka biasanya berbicara lantanguntuk menjual barang dari pedagang lokal. Periklanan modern baru muncul bersamaan dengan revolusi industri pada abad sembilan belas. Kelebihan produksi dari barang-barang untuk pasar yang ada di barat melalui teknik manufaktur baru yang mendorong untuk perluasan pasar melalui penaklukan para imperalis. Advertising pada awalnya berarti menarik perhatian kepada sesuatu atau memberitahukan atau menginformasikan seseorang tentang sesuatu. ${ }^{23}$ Don Slater mendefinisikan ulang fungsi dari advertising dan marketing melalui struktur pasar dan hubungannya. ${ }^{24}$

Brand, menurut David A.Aaker adalah "brand identity is unique set of brand associations that the brand strategies aspires to create or maintain. these associations represent what the brand stands for and imply a promise customers from the organization members.'25Pengertian tersebut menjelaskan bahwa identitas satu merek adalah keunikan yang ada pada merek tersebut dan janji yang benar-benar ditepati oleh perusahaan untuk konsumen.

${ }^{20}$ Suryanto, Pengantar Ilmu Komunikasi (Bandung, CV Puspataka Media, 2015), 439441.

${ }^{21}$ Suryanto, Pengantar Imu Komunikasi (Bandung, CV Puspataka Media, 2015), 442.

22 Zarkasy Effendi, Khutbah Jum'at Aktual (Jakrta, Gema Insani, 1999), 87.

${ }^{23}$ Gillian Dyer. Advertising as Communication, (London: Methuen, 1982), $\quad$ seperti dikutip dalam Gill Branston dan Roy Stafford, The Media Student's Book. Third Edition. (London: Routledge, 2003), 365-383.

24 Don Slater, Consumer Culture and Modernity. (Cambridge: Polity, 1997), 45. Sebagaimana dikutip dalam Gill Branston dan Roy Stafford, The Media Student's Book. Third Edition (London: Routledge, 2003), 365-383

25 Philip Kotler dan Ketvin Lane Keller, Managemen Pemasaran (Jakarta: Erlangga, 2009), 266-269. 
David Aaker, professor pemasaran dari UC Berkeler, mengatakan bahwa advertising and branding erat kaitannya dengan tiga hal, yaitu kehadiran, keunggulan dan konstruk diri. Seperti yang dapat dilihat di gambar di bawah ini:

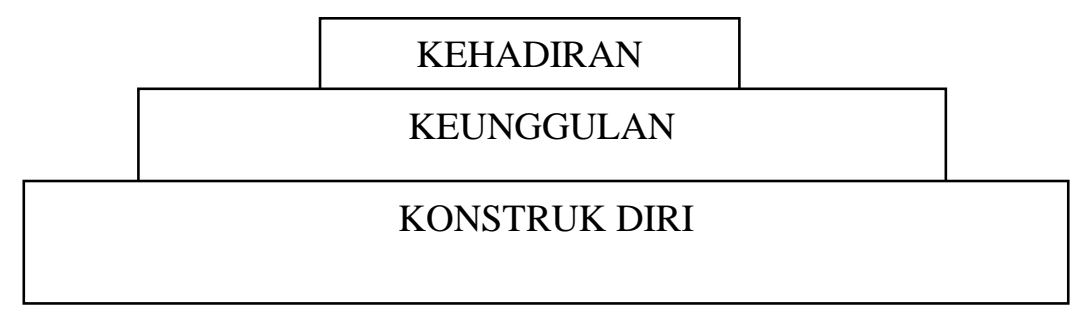

Dalam diagram tersebut menjelaskan. Hal pertama yang harus pengiklan lakukan adalah, kreatifitas iklan mereka harus mampu menghadirkan brand produknya di hati masyarakat. Artinya, memberitahu calon konsumen bahwa memang benar-benar ada produk X. Hal ini sependapat dengan Dyer (1982) yang mengatakan bahwa pertama adalah masyarakat tahu, memahami dan akhirnya memutuskan untuk membeli produk tersebut. ${ }^{26}$

Dalam dunia bisnis, salah satu faktor kesuksesan perusahaan adalah konsumen mengetahui suatu brand. Oleh karena nya, perusahaan harus mengontrol hal ini dengan penerbitan iklan. Masalah kehadiran ini, dapat dimulai dengan pertanyaan apakah saya mengetahuinya? Selanjutnya keunggulan, berarti apakah iklan produk ini menawarkan sesuatu yang lebih baik dibandingkan produk yang lain. Artinya, adanya komitmen dan kejujuran perusahaan yang didasarkan kepada komunikasi yang konstan dengan konsumen yang pada akhirnya memunculkan pemahaman sebenarnya dari produk tersebut.

Kemudian konstruk diri, apakah ia menggunakan standar ideologis yang sudah menjadi identitas kuat sebagai approved versions gender, kelas sosial, etnis, dan perbedaan umur. Artinya, adanya upaya penyebutan dalam iklan akan adanya konsep diri masyarakat, keseluruhan gambaran diri, yang meliputi persepsi seseorang tentang tentang diri, perasaan, keyakinan, dan nilai-nilai yang berhubungan dengan dirinya. ${ }^{27}$

Al-Qur'an telah melakukan konstruksi muslim yang ideal. Menurut Akbar S. Ahmed, karakteristik muslim ideal harus mengikuti konstruk yang telah ditetapkan dalam Al-Quran dan Hadith. ${ }^{28}$

Menurut surat Al-Isra', disebutkan bahwa Muslim itu wajib berbuat baik kepada orangtua, sanak saudara, orang muskin dan musafir. Setiap Muslim

${ }^{26}$ Gill Branston dan Roy Stafford. The Media Student's Book. Third Edition (Great Britain: Routladge), 365-383.

27 Philip Kotler dan Ketvin Lane Keller, Managemen Pemasaran (Jakarta, Erlangga, 2009), 266-269.

${ }^{28}$ Akbar S Ahmed, Discovering Islam Making Sense of Muslim History and Society, revised edition (New York: Routledge, 2001), 3-25. 
diperingatkan untuk tidak boros, membunuh, dan berzina. Sedangkan menurut Zuhaili, kriteria Muslim adalah: lelaki maupun perempuan yang mematuhi hukum Allah dan perintahNya, membenarkan rukun iman (beriman kepada Allah, malaikatNya, kitabNya, rasulNya, dan hari akhir), senantiasa melakukan ketaatan, benar dalam ucapan dan perbuatan, bersaar dalam melakukan ketaatan dan menjauhi kemaksiatan, tawadhu' kepada Allah dengan hati dan anggota badan, menyedekahkan harta yang diwajibkan dan disunahkan, mengerjakan puasa yang diwajibkan di bulan Ramadhan dan yang selainnya, memelihara kemaluan dari perbuatan yang haram, dan menyebut Allah dengan hati dan lisan. ${ }^{29}$

Media mempunyai peran yang sangat penting bagi perusahaan, yakni untuk melakukan pencitraan (image) atas suatu merek tertentu. Menurut Philip Kotler \& Kevin Lane Keller (2009), media dalam komunikasi pemasaran adalah sarana dimana perusahaan dapat berkontribusi terhadap ekuitas merekdengan menanamkan merek dalam ingatan dan menciptakan citra (image) merek, serta mendorong penjualan, dan memperluas pasar. ${ }^{30}$ Kontribusi komunikasi pemasaran dalam membentuk ekuitas merek akan membentuk pemahaman konsumen terhadap kesadaran merk. ${ }^{31}$

Untuk membedah kasus dalam penelitian ini, penulis akan menggunakan dua alat bedah. Alat bedah pertama adalah teori advertising and brandingDavid Aaker yang mempunyai tiga muatan, yaitu kehadiran, keunggulan dan konstruk diri. Alat bedaH kedua adalah karateristik perempuan milenial, yaitu connected, percaya diri, dan kreatif. Teori David Aaker akan digunakan untuk mengklasifikasi aktivitas instagram dan karakterisitk perempuan milenial akan dijadikan parameternya.

${ }^{29}$ Wahbah Zuhaili, et al. Al-Mausu\#'ah Al-Qur'aniyyah Al-Muyassarah. Imam Ghazali Masykur. Terj. (Jakarta: Almahira, 2009), 423.

30 Jatmiko, "Komunikasi Pemasaran Sebagai Strategi Memperluas Pasar"komunikologi 9:2 (September 2012): 89-98. Lihat juga dalam Philip Kotler \& Kevin Lane Keller. Marketing Management. 13th Edition (Jakarta: Erlangga, 2009).

${ }^{31}$ Branding memperoleh kekuatannya karena merk yang tepat dapat melampaui produk yang sebenarnya sebagai aset utama perusahaan. Dapat dilihat dalam Peter van Ham, "The Rise of the Brand State: The Postmodern Politics of Image and Reputation." Foreign Affairs 80:5 (Sep. - Oct., 2001): 2-6 Published by: Council on Foreign Relations Stable URL: http://www.jstor.org/stable/20050245 Accessed: 02-04-2015 08:05 UTC 
Bingkai Konsep

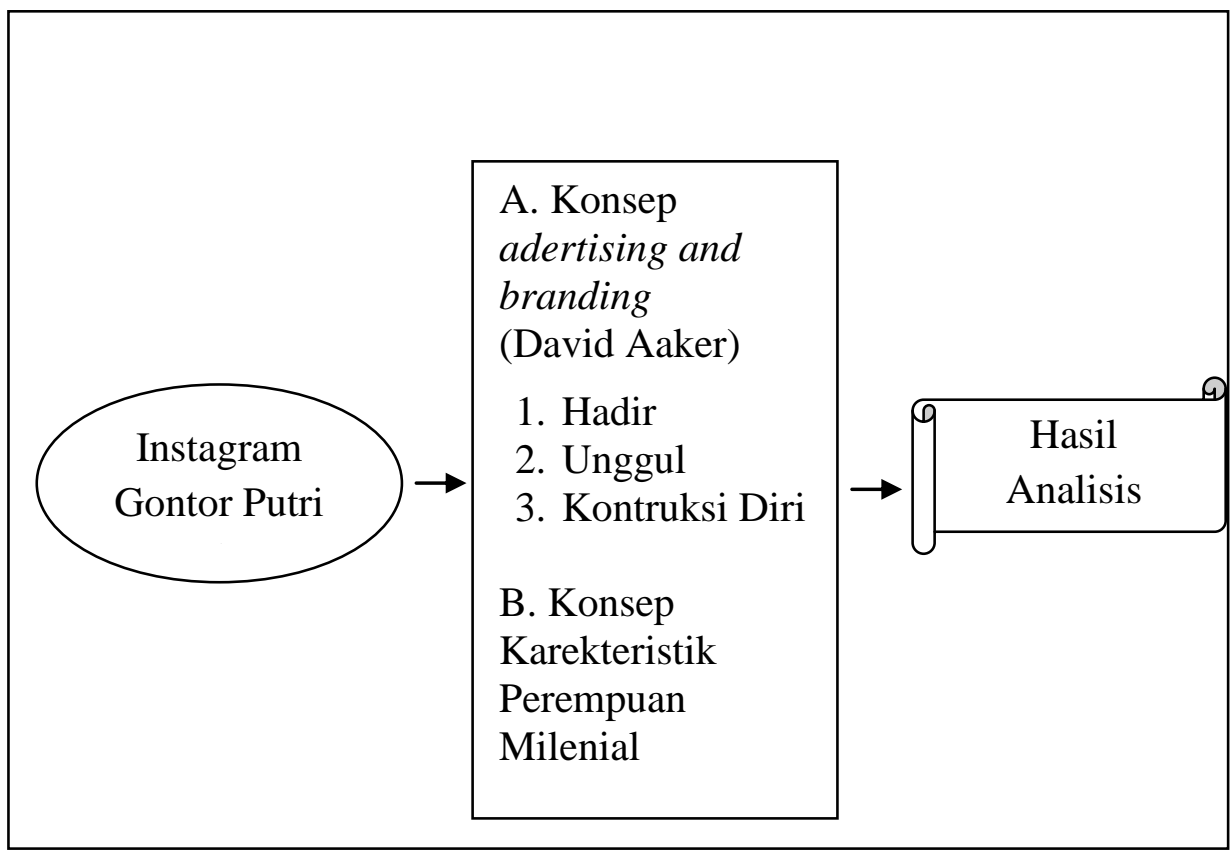

Bingkai konsep di atas dapat membantu menjelaskan skema dalam tulisan ini. Postingan instagram gontor putri 1 akan di analisis pesan-pesannya dari perspektif konsep advertising and branding. Konsep advertising and branding akan dijadiakan alat ukur untuk mengukur nilai-nilai. Setelah itu, hasil yang didapat akan di analisis, kemudian hasil nya akan dikontruksikan menjadi sebuah refleksi dan pernyataan akhir.

\section{Kehadiran.}

Setelah penulis telusuri melalui berbagai channel, termasuk bertanya pada alumninya, pondok pesantren modern gontor putri 1 mempunyai akun insagram resmi, yaitu@gontorputri1 (follower 1581), namun nampak tidak terurus. Dalam akun tersebut hanya ada 11postingan, dan memposting terakhir pada tanggal 26 Agustus 2018. Awalnya penulis kesulitan mencari akun gontor putri 1, yang banyak beredar adalah akun ig yang tidak resmi, yaiu @gontorputricantik (follower 1281), @gontorputri_satu (follower 1631), dan tagar \#gontorputri1 (jumlah tagar 3094).32

32 Tagar adalah instrument dalam instagram yang berfungsi sebagai dokumentasi. Setiap orang yang mempunyai tagar yang sama, dapat di cek secara bersamaan. 

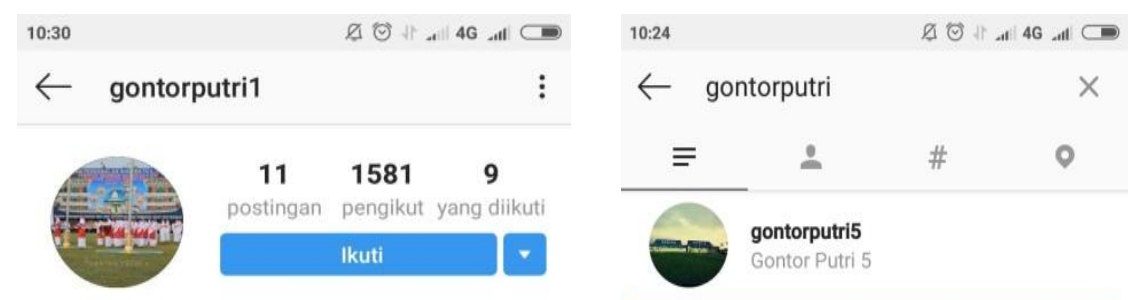

Official Page of Gontor Putri 1 www.gontor.ac.id/putri1/
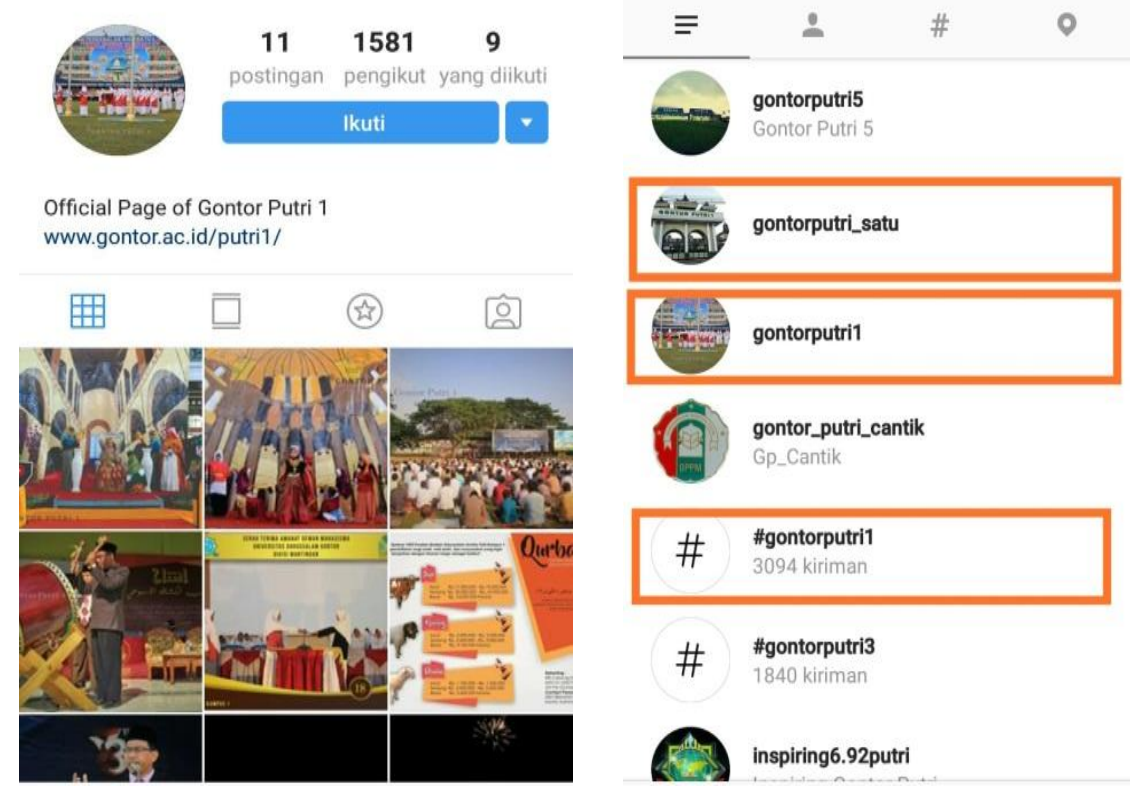

Gp_Cantik
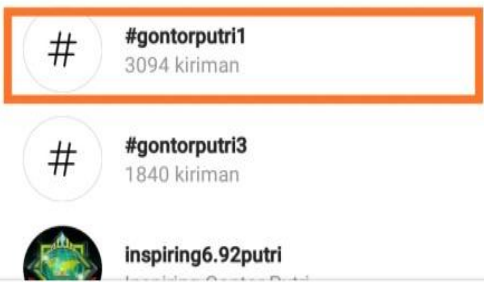

Gambar 2: Akun Istagram Pesantren Putri Pondok Modern Darussalam Gontor

Melihat kondisi ini, nampaknya gontor putri 1 belum memiliki kesadaran penuh untuk terlibat dalam membranding diri di media kekinian. Gontor putri 1 belum terkoneksi baik dengan dunia instagram. Dengan tidak terkoneksinya gontor 1 putri di instagram, maka masyarakat akan kesulitan menemukan brand pondok tersebut. Selama gontor putri 1 diresmikan, hanya ada 11 postingan di akun mereka. Jumlah tersebut membuat masyarakat kecewa, karena kata "modern" yang disematkan dalam nama pondok pesantren ternyata tidak sesuai dengan realitas. Dapat dikatakan kehadiran gontor putri 1 melalui instagram kurang diperhatikan. Padahal, salah satu kriteria brand yang diandalkan adalah elemen tersebut dapat di ingat melalui media sosial.

Modern dalam nama pondok pesantren seharusnya bukan hanya ada pada sistem pendidikannya dan kegiatannya saja, namun ikut diimbangi dengan keterlibatan pesantren tersebut dengan media sosial. Penulis telusuri lebih lanjut dalam akun instagram dengan nama@gontor.id, jumlah follower 3062 orang. Dari 47 postingan, tidak ada satupun kegiatan yang mengatasnamakan gontor putri satu. Begitu juga di akun @gontormendunia, jumlah follower 10.1 ribu. Kebanyakan postingan di akun tersebut juga di dominasi oleh laki-laki.

Padahal, jika kehadiran gontor putri 1 melalui instagram dengan kegiatankegiatan yang menarik dan penampilan yang elegan diperhatikan dengan serius dan 
berkonsep, bukan tidak mungkin juga mampu memfilter konten-konten negaif yang berkeliaran di instagram. Akun instagram gontor putri menjadi salah satu alternatif kegiatan remaja putri yang menjadi kegiatan representasi yang akan mereka laksanakan di lingkungan, komunitas dan sekolah mereka masing-masing. Secara sadar, akun instagrram tersebut juga akan menjadi akun amar ma'ruf nahi munkar.

\section{Keunggulan}

Keunggulan Pondok Pesantren modern Gontor putri 1 dapat terlihat dalam panca jiwa dan motto pondok modern gontor. Panca jiwa berbunyi keikhlasan, kesederhanaan, berdikari, ukhuwah Islamiyah dan kebebasan. Sedangkan motto berbunyi berbudi tinggi, berbadan sehat, berpengeahuan luas dan berfikiran bebas. Selain itu, ijazah lulusannya juga mendapatkan pengakuan pemerintah Republik Persatuan Arab (RPA), Mesir, Kerajaan Saudi Arabia, Pakistan dan lainnya. Secara ekplisit, untuk masalah keunggulan, pondok modern gontorputri 1 selain belajar tentang ilmu agama, juga belajar tentang ilmu dunia. Artinya, santri akan di bekali dua hal sekalaigus.

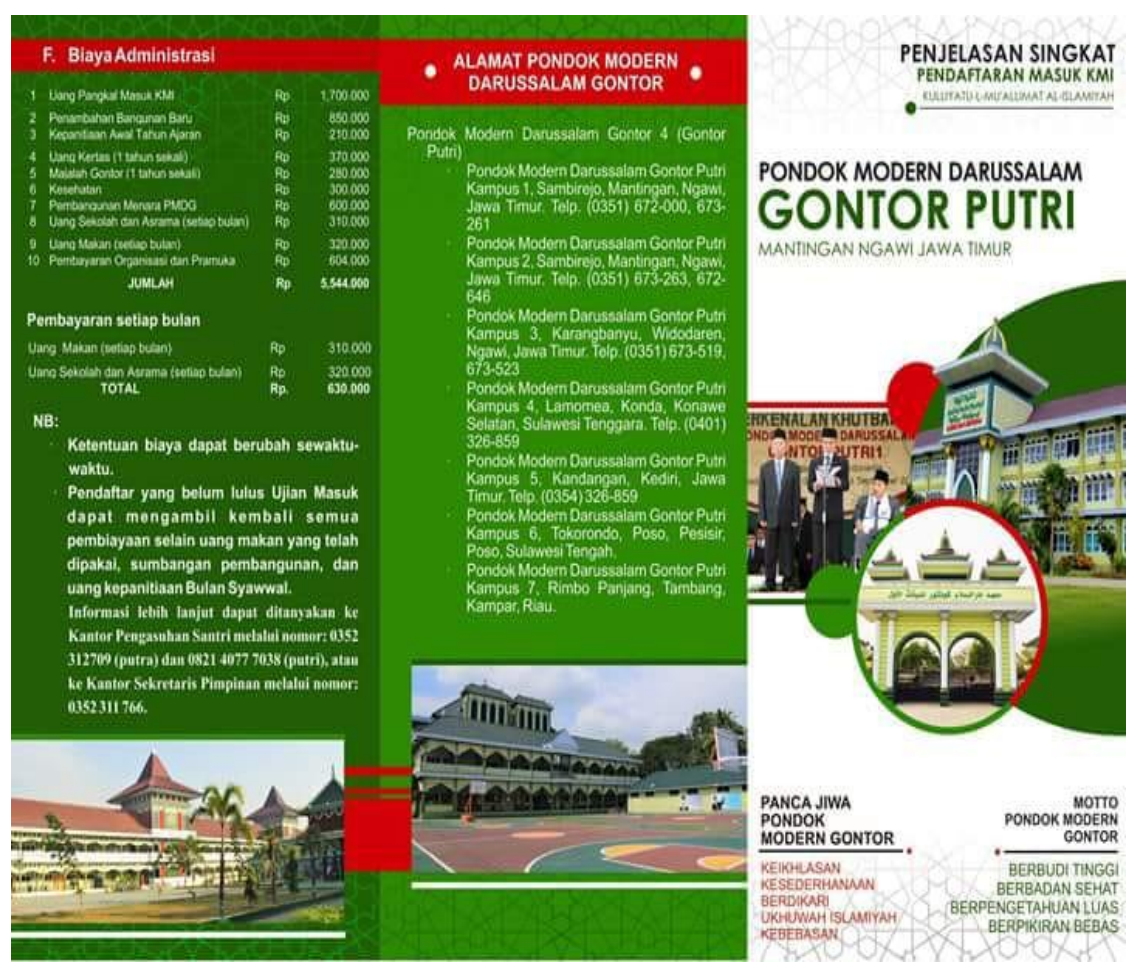

Gambar 3: Brosur penerimaan santri baru Pesantren Putri Pondok Modern Darussalam Gontor 
Sayangnya,keunggulan ini tidak nampak di akun instagram@gontorputri1. Penulis perlu menelusuri lebih dalam data yang berkaian dengan keunggulan. Padahal jika keunggulan ini mudah ditemukan, pasti sangat membantu masyarakat mencari informasi terkait. Keunggulan gontor putri 1 ini tentu saja sangat bagus, namun bagus saja tidak cukup. Keunggulan yang bagus tersebut tidak akan nampak dipermukaan, karena idak dipromosikan dengan baik. Dewasa ini menjadi lembaga yang informatifdan ramah teknologi adalah keniscayaan jika tidak mau dianggap konvensional. Keunggulan ini tertupi karena memang tidak diperuntukkan untuk terbuka dan dibuka masyarakat.

\section{Konstruk diri}

Pondok pesantren Darussalam gontor puttri memiliki slogan orientasi, yaitu menjadikan satriwati wanita muslimah, sholihah dan wanita teladan. Slogan tersebut penulis dapatkan di web gontor.ac.d/gontor-putri-1. Dapat terlihat bahwa adanya usaha gontor putri dalam hubungan slogan yang dipakai dengan menghadirkan tersebut di masyarakat. Slogan singkat adalah slogan yang mudah diingat. Sebagaimana disebutkan bahwa ingatan atau sering disebut memory adalah sebuah fungsi dari kognisi yang melibatkan otak dalam pengambilan informasi. Pada umumnya para ahli memandang ingatan sebagai hubungan antara pengalaman dengan masa lampau. Apa yang telah diingat adalah hal yang pernah dialami, pernah dipersepsinya, dan hal tersebut pernah dimasukkan kedalam jiwanya dan disimpan kemudian pada suatu waktu kejadian itu ditimbulkan kembali dalam kesadaran. ${ }^{33}$

Muslimah, sholihah dan wanita teladan dalam penjabarannya secara eksplisit sejalan dengan karakerteristik perempuan milenial yaitu connected, percaya diri dan kreatif. Hal ini terlihat dari atribut-atribut yang digunakan dalam postingan instagram@gonorputri1. Yaitu pada postingan tertanggal 26 Agustus 2018, akun@gontorputri1 memposting kegiatan gebyar seni darussalam, yang menunjukkan kegiatan santri perempuan sedang melaksanakan drama dengan kostum Turki. Melakukan aktivias drama berpakaian ala Turki dengan gaya nyentrikdan mendalami peran, adalah contoh dari pribadi yang kreatif, mandiri dan cerdas.

33 Alizabeth B. Hurlock, Development Psychology, 5th Editon. Diterj. Oleh Istiwadayanti dan Soedjarwo, Psikologi Perkembangan (Jakarta: Erlangga, 2007), 206-209. 


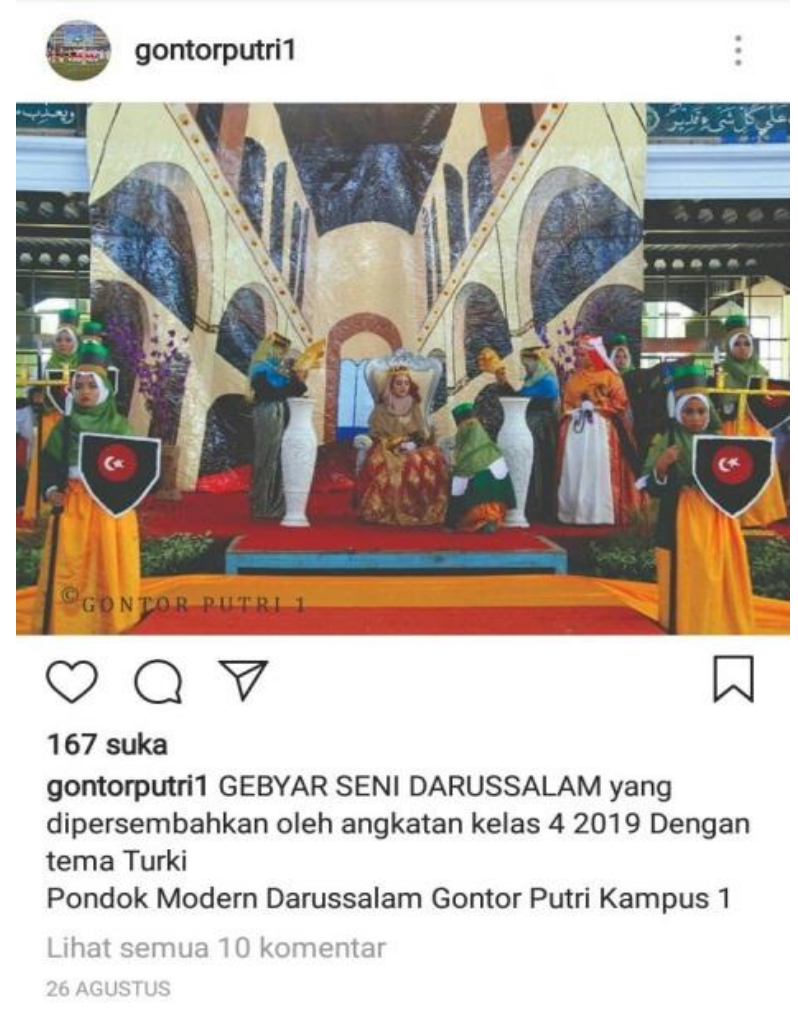

Gambar 4: Gebyar seni Pesantren Putri Pondok Modern Darussalam Gontor

Kreatif karena menggunakan cerita yang anti mainstream, mandiri terlihat pemerannya adalah semua wanita. Dan dibutuhkan kecerdasaran untuk membangun sebuah drama yang sukses. Percaya diri dan mandiri juga terlihat dalam postingan tertanggal 18 Agustus 2018, yaitu kegiatan drama arena dengan tema Precious Generation.Santri perempuan juga diperkenankan untuk membuat kepengurusan dari,oleh dan untuk mereka sendiri. Dengan begitu, santri perempuan akan mandiri dan mempunyai kesempatan untuk saling berinteraksi dalam sebuah struktural organisasi. Mereka juga belajar memimpin, belajar berkomunikasi, belajar memecahkan masalah,dan tentu belajar mencari solusi bersama-sama. Santriwati juga diperkenanakn menjadi petugas upacara. Tampak dalam akun@gontorputri1 18 Agustus2018.

Kegiatan-kegiatan yang ditunjukkan mengindikasikan bahwa gontor putri 1 mengonstruksikan dirinya sesuai dengan karakteristik perempuan milenial. Dalam konstruk diri, terlihat ada upaya gontor putri 1 untuk membranding diri. Penulis tidak yakin apakah ini memang sengaja di publikasikan untuk brand, atau keisengan pengurus semata. Karena postingan tersebut terlihat asal posting saja, tidak menggunakan konsep yang matang. 


\section{Penutup \\ Kesimpulan}

Terlihat ada upaya-upaya yang dilakukan ponndok modern darussalam gontor puri 1 dalam membranding diri. Gontor putri 1 membranding dirinya untuk dapat hadir di hati masyarakat. Slogan-slogan singkat dipakai agar memudahkan masyarakat untuk mengingat pondok tersebut. Konstruk diri yang digambarkan oleh gontor putri 1 berusaha merepresentasikan gambaran perempuan milenial Indonesia secara paripurna. Perempuanyang mandiri, kreatif dan berfikir bebas.

Dalam tulisan ini, brand yang dilakukan gontor putri 1 di instagram ingin membentuk konsep yang ideal dalam sudut pandang Islam. Kehadiran, keunggulan, dan konstruk diri dikemas begitu baik. Namun hal ini tidak dilakukan dengan serius melalui kanal media sosial, khususnya instagram. Hanya dilakukan seadanya saja. Nampaknya tidak ada tim khusus yang membranding diri melalui media sosial. Padahal jika hal ini dilakukan dengan serius, akan berdampak baik bagi gontor putri 1. Dan kemungkinan akan menginspirasi pondok pesantren lain untuk melakukan hal sama, yaitu brand melalui mediasosial. Sehingga brand "ndeso" yang disematkan pondok pesantren akan berubah dengan usaha bersma. Pada akhirnya akan meningkatkan kepercayaan masysrakat untuk menitipkan anak perempuannya mengenyam pendidikan di pondok pesantren.

Penulis meyakini ada banyak kegiatan positif yang dapa dibagikan oleh pondok pesantren modern gontor putri 1 untuk membranding dirinya di media sosial. Kegiaan pagi sampai malam di pondok pesantren diyakini mempunyai nilainilai yang jika disebarluaskan melalui media sosial dengan proporsi yang seimbang (tidak melalmpui batas), merupakan kegiatan amar ma'ruf nahi munkar. Usaha rebranding pondok pesantren melalui media sosial (instagram, facebook, twitter, youtube) harus menjadi salah satu fokus utama pemangku pondok pesantren untuk dikampanyekan, dan juga dibantu oleh pihak terkait. Jika dilakukan dengan serius, pondok pesantren Indonesia akan menjadi pilihan utama masyarakat modern untuk menyekolahkan anaknya, dan Indonesia akan memiliki putra-putri bangsa yang handal dan berkarakter.

Media sosial mengubahpemaknaan individu terhadap teks, gambar atau pesan. Hal ini sangat memengaruhi motivasi individu dan atau komunitas dalam mengambil keputusan dan tindakan. Pondok pesantren masa depan adalah pesantren multidimensi, multimedia, multi interdisipliner yang mampu menarik perhatian masyarakat terhadap pesan yang diciptakannya. Hal itu mudah terwujud jika pesantren sadar pentingnya brand. Brand pesantren kekinian harus bisa diterima, dipahamai dengan mudah oleh semua kalangan.

Branding merupakan bentuk komunikasi yang digunakan untuk memberik citra baik kepada audiens (pemirsa, pembaca atau pendengar). Tujuan nya untuk mengarahkan wajah kepada konsumen terhadap suatu lembaga atau produk. Kegiatan branding melibatkan banyak faktor. Pertama, profit-oriented pengelola 
lembaga yang hanya melihat rating. Keuda, market-oriented penjajak produk 'khas' yang hanya melihat pasar. Ketiga, moment-oriented, dan non-oriented viewers atau para penonton yang kadang tidak punya alasan menonton selain faktor kebiasaan.

Terlihat ada upaya-upaya yang dilakukan gontor putri 1 putri dalam membranding perempuan untuk hadir di hati masyarakat. Slogan-slogan singkat mereka pakai agar memudahkan masyarakat untuk mengingat kelebihannya

\section{Daftar Pustaka}

Atkin, Charles, Human Communication Principles, Contexts and Skills. New York, Martin Press, 1980.

Aziz, Moh Ali, Ilmu Dakwah. Jakarta: Kencana, 2009.

Bakti,Andi Faisal, Globalisasi: Dakwah Cerdas Era Globalisasi Antara Tantangan Dan Harapan, https://c3huria.com/2015/01/28/globalisasi-dakwah-cerdas-eraglobalisasi-antara-tantangan-dan-harapan/ di akses pada 17 Maret 2015.

Branston, Gill dan Roy Stafford. The Media Student's Book Third Edition. Great Britain: Routladge.

Carroll, Evan and John Romano, "Your Digital Afterlife: When Facebook, Flicker and Twitter Are Your Estate, What's Your Legacy?” Berkeley: New Riders, 2011.

Dyer, Gillian. Advertising as Communication. London: Methuen, 1982.

Hasan, Akhmad Muawal, Ketimpangan Gender dan Kendali Perempuan Milenial, diakses di https://tirto.id/ketimpangan-gender-dan-kendali-perempuanmilenial-cnb5.

Hurlock, Alizabeth B. Development Psychology, 5th Editon. Diterj. Oleh Istiwadayanti dan Soedjarwo, Psikologi Perkembangan. Jakarta: Erlangga, 2007.

Kotler, Philip dan Ketvin Lane Keller, Managemen Pemasaran. Jakarta: Erlangga, 2009.

Maarif, Syamslul, Pesantren VS Kaapitalisme Sekolah, Semarang: NEED'S Press, 2008.

Ham, Peter van, "The Rise of the Brand State: The Postmodern Politics of Image and Reputation.” Foreign Affairs 80:5 (Sep. - Oct., 2001): 2-6 Published by: Council on Foreign Relations Stable URL: http://www.jstor.org/stable/20050245 Accessed: 02-04-2015 08:05 UTC

Slater, Don. Consumer Culture and Modernity. Cambridge: Polity, 1997. 
McQuail, Denis dan Seven Windahl, Communication Models for Study of Mass Communications. New York: Longman, 1993.

Suryanto, Pengantar Ilmu Komunikasi, Bandung, CV Puspataka Media, 2015.

Susanti, Emy, Pemikiran Kartini dan Peran Perempuan di Era Milineal. Diakses melalui www.unair.ac.id/uploads/file/978da696984c5a895213abf56b6e0c43.pdf

Zamachsyari, Dhofier, Tradition and Change in Indonesia Islamic Education, Jakarta: DEPAG: 1995.

http://www.gontor.ac.id/pondok-modern-darussalam-gontor-putri-1 
40 | Jurnal Dakwah dan Komunikasi, Vol. 4 , No.1, 2019

Halaman ini sengaja di kosongkan 